\title{
The Role of Government Affiliation in Explaining Firm Innovativeness and Profitability in Emerging Countries: Evidence from China
}

\begin{abstract}
Drawing from institutional polycentrism, we advance understanding of how affiliation with different government levels influences innovativeness and profitability in emerging countries. Our framework suggests that as different government levels vary in their objectives and resources, they affect firm innovativeness vis-à-vis profitability in qualitatively different ways. The analysis of 18,430 Chinese firms shows that affiliation with higher-level governments enhances firms' innovativeness, whereas affiliation with lower-level governments is effective for enhancing profitability. Our framework also clarifies how location-specific institutional substitution occurs, indicating that the usefulness of government affiliation for innovativeness depends on how effectively legal institutions protect intellectual property in each region.
\end{abstract}

Keywords: State capitalism, government affiliation, political ties, innovation, profitability, China, emerging countries. 


\section{Introduction}

Although the international business literature has recognized that emerging market enterprises (EMEs) become more innovative, we still know very little about the determinants of their innovativeness (Krammer \& Jiménez, 2019; Hoskisson, Wright, Filatotchev, \& Peng, 2013; Kafouros, Wang, Piperopoulos \& Zhang, 2015). Firms in developed countries innovate by relying on strong factor markets and institutional frameworks that protect intellectual property rights (IPR) (Li, Chen, \& Shapiro, 2010). However, state capitalism and certain institutional idiosyncrasies render such innovation strategy less appropriate for EMEs (Xu and Meyer, 2013) and prompt the need to develop new perspectives for understanding EMEs' strategy (Musacchio \& Lazzarini, 2014; Wood \& Wright, 2015; Wright, Filatotchev, Hoskisson, \& Peng, 2005). Motivated by this view, we examine how state capitalism in the form of firm affiliation with different levels of government in China influences firm innovativeness (in terms of new product development) and profitability, and how this relationship varies across regions depending on legal (IPR-related) institutions.

Firm-government affiliations are prominent in emerging countries. However, due to the institutional context of emerging countries, there are significant differences in the levels or hierarchical ranks of governments to which firms are formally connected (Wang, Hong, Kafouros, \& Wright, 2012). Many Chinese EMEs are affiliated with higher government levels (i.e., state or provincial levels), whereas others are affiliated with lower government levels (i.e., county level or below). As governments have a profound effect on how firms create value in emerging countries (Shi, Markóczy, \& Stan, 2014; Zhou, Gao, \& Zhao, 2017), understanding such variations can help us explain the determinants of EMEs' innovativeness and how institutions matter in these contexts (Kafouros \& Aliyev, 2016a; Wright et al., 
2005; Xu \& Meyer, 2013; Zhou et al., 2017). It is also practically important given that state control represents up to 20 percent of the stock market value in the world (Musacchio \& Lazzarini, 2014) and many firms from China have evolved into Fortune Global 500 MNEs (Zhou et al., 2017).

Our framework draws from the theory of institutional polycentrism. The theory recognizes the existence of multiple levels of power and different rule-setting institutional authorities (Batjargal, Hitt, Tsui, Arregle, Webb, \& Miller, 2013; Ostrom, 2011). It postulates that organizational outcomes depend on the 'confluence' of different types and levels of institutions (Ostrom, 2011). Confluence may involve either institutional substitution (whereby firms' affiliation with government compensates for less useful external institutions) or institutional complementarity (whereby affiliation with government is aligned with and reinforces the advantages of external institutions; Ostrom, Schroeder, \& Wynne, 1993; Singh, Darwish, Wood, \& Mohamed, 2017).

Building on this reasoning, we develop the premise that firm affiliation with different levels of government not only affects firm innovation vis-à-vis profitability in a qualitatively different way, but may also complement or substitute external institutions in influencing innovativeness and profitability. Hence, our study differs from prior research that considers the effects of political ties and government ownership, but implicitly assumes that governments within a country (regardless of their levels) are homogenous in their objectives and therefore in how they influence firm outcomes (Shi et al., 2012; Musacchio and Lazzarini, 2014; Xu, Lu, \& Gu, 2014).

Our analysis advances understanding of the role of state capitalism in three ways. First, it contributes to research about the role of government ties (Okhmatovskiy, 2010; Shi et al., 2012; Sheng, Zhou, \& Li, 2011) by showing that the value of such ties does not depend solely on their existence and strength but 
also on the level at which they exist. This distinction is theoretically useful because different government levels have different priorities and resources (Bai, Lu, \& Tao, 2006; Sun, Mellahi, \& Thun, 2010), exert different institutional pressures and influence firm objectives and outcomes differently.

Second, it contributes to studies that have examined how government ownership affects firm outcomes (Musacchio \& Lazzarini, 2014; Xu, Lu, \& Gu, 2014; Zhou et al., 2017), but have not explored how different hierarchical ranks of government affect firm innovativeness vis-à-vis firm profitability. In this respect, our analysis shows that affiliation with higher government levels is effective in enhancing firms' willingness and ability to innovate, whereas affiliation with lower government levels helps firms increase profitability.

Finally, our analysis demonstrates that the usefulness of government affiliation varies across locations, depending on region-specific legal institutions associated with IPR protection. In showing that firms leverage government affiliation as an alternative means to ineffective IPR institutions, our framework explains why the usefulness of political ties varies across locations, how legal institutions reinforce or decrease their usefulness, and when the benefits of political ties outweigh the costs (Lester, Hillman, Zardkoohi, \& Cannella, 2008).

\section{Conceptual framework}

\subsection{Organizational Political Ties in the Form of Government Affiliation}

Affiliation with government is a form of organizational political ties - i.e. connections between the firm and government through (formal) affiliation (Sun, Mellahi, \& Wright, 2012). Such ties are particularly prevalent in emerging countries, such as China, that preserve fundamental pillars of state 
capitalism (Musacchio \& Lazzarini, 2014). Organizational ties involve a formal relationship whereby government provides advantages and in exchange the firm supports government objectives that may deviate from the firm's strategic priorities (Wang et al., 2012). They differ from personal political ties that typically involve informal relationships between corporate executives and political actors or formal ties that involve political actors sitting on the firm's executive board without necessarily representing the government (Fernández-Méndeza, García-Canal, \& Guillénc, 2018; Grosman, Okhmatovskiy, \& Wright, 2016). Personal ties can facilitate the exchange of favours but, unlike organizational ties, they are terminated when executives leave the firm (Sun et al., 2012) or when politicians rotate positions across departments and jurisdictions (Sheng et al., 2011).

Organizational political ties in the form of government affiliation vary in terms of level. Many firms in China are affiliated with government at different levels, ranging from the state and provincial levels to the city and county levels or lower (Li, Cui, \& Lu, 2014; Wang et al. 2012). There are three types of government affiliated firms (Li et al., 2014; Cui \& Jiang, 2012). The first type includes traditional SOEs that are affiliated with government by default. Being the founder and shareholder, government has tight control over decision-making in these firms.

The second type includes SOEs with partial state ownership (Grosman et al., 2016) but the government may keep veto rights for key decisions (Cuervo-Cazurra, Inkpen, Musacchio, \& Ramaswamy, 2014). Due to market-oriented reforms, these companies are either dispersedly controlled or privately controlled but government remains a smaller (but still influential) shareholder (Xu et al., 2014). The third type is town and village enterprises (TVEs). These are administered by governments at town or village levels (Tian, 2000) and can be considered as a special form of SOEs. 
In all these three groups of firms, government maintains some control over senior managerial appointments and strategic investments regardless of the level of ownership in the firm. Although firms in different countries may be tied with government through different means, they are still connected to different levels of government given that many other emerging countries, such as Uruguay and Kenya, are characterized by higher and lower government tiers (Choi, Jia, \& Lu, 2015).

From a state capitalism perspective, consideration of government levels is theoretically useful because different levels of government are associated with different institutional prescriptions and have different objectives and priorities. Governments at higher levels (e.g., central) control key industries and resources and aim at improving national safety and global competitiveness ( $\mathrm{Li}$ et al., 2014), whereas local governments want to increase local output and reduce local unemployment (Jin et al. 2005). Governments at different levels may possess overlapping political power and authority (Choi et al., 2015). Although higher-level governments have more authority, lower-level governments are directly involved in the implementation of initiatives. They can therefore circumvent the objectives of higher-level governments (Choi et al., 2015) and encourage the firms they govern to pursue their own objectives (Li et al., 2014).

\subsection{Institutional Polycentrism}

Institutions differ considerably across subnational regions in China (Meyer \& Peng, 2016; Hong, Wang, \& Kafouros, 2015; Zhou et al., 2017). Administrative decentralization has created heterogeneity in the role of governments at different levels, allowing them to implement policies set by high-level governments in different ways (Li, Xia, Shapiro, \& Lin, 2018). These institutional 
variations across regions and government levels influence firms in terms of their objectives (Wang et al., 2012), access to resources (Sheng et al., 2011) and the ability to overcome institutional voids (Zhou et al., 2017).

Given the existence of a multi-layered government system in China and our objective to explain the role of affiliation with different government levels, we draw on the theory of institutional polycentrism. The theory postulates that the existence of multiple rule-setting authorities in each environment results in polycentric institutions, which refer to 'institutional rules and norms that originate from, are situated in and are enforced by numerous decision-making power centres' (Batjargal et al., 2013, p.1026). It also postulates that when certain institutions are either ineffective or not aligned with the objectives of organizations, organizations seek alternative institutions to compensate for those that are inconsistent or less useful (Ostrom et al., 1993; Zheng, Singh, \& Mitchell, 2015). This process leads to institutional substitution (Batjargal et al., 2013). The theory also recognizes that different but often overlapping centres of authority 'confluences' opportunities and organizational actions (Ostrom, 2010). As a result, environments are characterized by institutional multiplicity, i.e., by a dynamic interplay and co-integration of diverse norms and prescriptions that make the effects of one set of rules contingent on others (Batjargal et al., 2013, Ostrom, 2011).

Applying this theory to our study, we contend that due to polycentric settings and confluence (Teagarden, Glinow, \& Mellahi, 2018), firms are affected not only by different levels of governments with which they are affiliated but also by other external institutions. They must therefore manage and comply with different pressures depending on the level of government affiliation and location-specific idiosyncrasies. The theory of institutional polycentrism helps us build a theoretical foundation for our 
overarching reasoning that firms' innovativeness and profitability are shaped differently by the varying objectives, institutional pressures and prescriptions associated with different levels of government and by legal IPR-related institutions that are specific to certain locations (sub-national regions).

\subsection{Mechanisms through which Government Affiliation Affects Firm Innovativeness and Profitability}

Firm innovativeness (or innovation performance) in this study refers to the development and market introduction of a new, redesigned or substantially improved product (Crossan \& Apaydin, 2010; McCann \& Oxley, 2012; OECD, 2005). Affiliation with government is not always beneficial. It may lead to inefficient structures, increase bureaucratic interference, corruption and crony capitalism (Choi et al., 2011), and force firms to deviate from their strategy to serve political and social objectives (Li, Xia, Shapiro, \& Lin, 2018; Tihanyi, Aguilera, Heugens, van Essen, Sauerwald, Duran, \& Turturea, 2019; Zhou et al., 2017). Understanding when the positive effects of government affiliation dominate the negative ones requires consideration of the mechanisms through which government affiliation influences firm innovativeness and profitability.

Starting from the first relationship, we contend that affiliation with government affects firm innovativeness through three distinct mechanisms that influence the firm's (1) willingness to innovate by exerting coercive and regulatory institutional pressures; (2) ability to develop innovations by providing resources, knowledge and intermediary services; and (3) ability to appropriate value from innovation by providing complementary assets and protection.

First, regulative, normative and cognitive structures and processes create pressures, incentives and opportunities that influence firms' strategic priorities (Scott, 1995), including their willingness to 
innovate. Due to institutional multiplicity, firm strategies must be congruent with the institutional demands of the corresponding level of government at which they are affiliated. For example, the ‘indigenous innovation' framework of the central government in China creates strong coercive pressures that push firms affiliated at this level to innovate.

Second, government affiliation influences a firm's ability to develop innovations by compensating for inefficient markets for resources and by providing access to licenses, permits and administrative privileges. Certain resources are exclusively available to politically connected insider firms (Fernández-Méndeza, García-Canal, \& Guillénc, 2018; Liu, Yang, \& Augustine, 2019; Tihanyi, Aguilera, Heugens, van Essen, Sauerwald, Duran, \& Turturea, 2019; Wood \& Wright, 2015). These can complement weak internal innovation capabilities (Kafouros, Wang, Piperopoulos, \& Zhang, 2015; Luo \& Bu, 2018) and help firms overcome environmental uncertainties (Li, Xia, Shapiro, \& Lin, 2018), enhancing therefore their ability to innovate.

Third, weak enforcement of IPR laws in emerging markets affects firms' ability to appropriate value from innovation. Government affiliation helps firms circumvent institutional barriers (Peng \& Luo, 2000) and protects them from external expropriation and unlawful imitations (Ivus, 2015). Real world examples (e.g., the lawsuit of GM against Cherry) show that the governments of emerging markets may also act as an arbitrator and help their affiliated firms settle legal IP disputes.

In addition to firm innovativeness, government affiliation may also influence firm profitability by affecting revenue-generating opportunities as well as the cost of obtaining resources and information. First, as governments control a wide variety of resources (Clegg, Voss \& Tardios, 2018; Musacchio \& Lazzarini, 2014; Zhang, Qi, Wang, Zhao, \& Paware, 2019), they can help affiliated firms improve their 
profitability by providing low-cost access to resources (Wang et al., 2012; Wang, Sutherland, Ning, Wang, \& Pan, 2018; Zhou et al., 2017) and by offering finance at below-market rates (Khwaja \& Mian, 2005). Second, governments can provide affiliated firms with specific intelligence about the market and with intermediary services that are needed for the exploitation of firm assets (Sun, Mellahi, \& Thun, 2010). They can also treat affiliated firms favourably, reduce environmental uncertainty, protect them from competition and help them achieve oligopolistic positions (Tihanyi et al., 2019), increasing therefore economic rents.

\section{Hypotheses}

\subsection{Effects of government affiliation on firm innovativeness and profitability}

We hypothesize that firms' affiliation with higher government levels can enhance their innovativeness, whereas affiliation with lower government levels is more advantageous for firm profitability. Our reasoning does not necessarily suggest that innovation and profitability as firm objectives are at odds with each other. However, it recognizes that each government level may differ in its objectives (Bai et al., 2006) and therefore it may motivate and enable firms to prioritize and implement different strategies.

Affiliation with higher-level governments in China may enhance firms' innovativeness through the causal mechanisms discussed in the previous section. First, due to institutional multiplicity (Ostrom, 1993), affiliation with different levels of governments differentially influence the willingness of firms to develop innovations. Each government level differs in the national initiatives and directives it embraces and in the incentives it provides (Bai et al., 2006). Higher-level governments are particularly concerned 
with technological progress and with globally oriented strategic objectives that improve the nation's global competitiveness. In the context of China, institutional pressures arise from the central government's objectives to 'improve self-innovation capability and build a nation of innovation' (Bai \& Li, 2011) and to globalize the country (Wang et al., 2012). Therefore, firms that are affiliated with higher-level governments receive stronger pressure to act as policy instruments ( $\mathrm{Li}$ et al., 2014) and to achieve innovation-related goals. Affiliation with higher-level government also incentivizes firms to innovate by providing legitimacy (Wang et al. 2012) and by reducing environmental uncertainty (Li et al., 2018) when they develop technologies.

Second, affiliation with higher levels of government improves firms' ability to create innovations. Higher-level governments are powerful and can provide access to the outputs of publicly funded R\&D that augment the technological portfolios of firms. Access to new resources facilitates experimentation and buffers firms from the risks of pursuing innovative activities (Sheng et al., 2011). Furthermore, affiliation with higher-level governments makes firms more influential (Ahuja \& Yayavaram, 2011). It therefore enables firms to affect regulatory systems in a favourable manner (Hillman et al., 1999), benefit from privileged information about national strategic initiatives and policies, and anticipate how innovation systems will evolve.

Third, the level of government affiliation affects firms' ability to appropriate value from innovation. Because governments at higher levels control complementary assets such as licenses and service distribution channels (e.g., in telecommunications; Soh \& Yu, 2010), they can aid their affiliated firms in commercializing technology. In addition, because IPR protection in emerging countries such as China depends not only on the legal system but also on political ties (Li, Park, \& Li, 2004), affiliation 
with higher level governments reduces the risk of value misappropriation. Higher-level governments have authority and may 'stand above the law' (Frye \& Shleifer, 1997). Therefore, they can help their affiliated firms decrease uncertainty regarding IPR enforcement, litigate IP-related infringements and reduce risks related to unfair court rulings. Accordingly, we introduce the following hypothesis:

H1: Affiliation with higher levels of government is more effective than affiliation with lower levels of government for enhancing firms' innovativeness.

In contrast, we expect affiliation with lower-level governments to be more effective than affiliation with higher-level governments in affecting both the willingness and ability of firms to enhance their profitability. Lower-level governments in China are responsible for enhancing fiscal revenue and tax income at the local level (Bai et al., 2006; Boisot \& Meyer, 2008; Li et al., 2014). Fiscal decentralization in the country aligns the interests of businesses with the objectives of local government rather than with those of higher-level governments (Yan \& Chang, 2018). Firms that are affiliated with lower-level governments are under institutional pressure to serve as commercial vehicles of such governments and help them achieve their goals ( $\mathrm{Li}$ et al., 2014). These pressures in turn increase the willingness of these firms to prioritise short-term and less uncertain initiatives that can generate revenue and profits quickly (Gavetti, Greve, Levinthal, \& Ocasio, 2012).

Furthermore, affiliation with lower-level governments may enhance the ability of firms to increase profitability through the two mechanisms discussed earlier (namely, revenue-generating opportunities and the cost of obtaining resources and information). First, lower-level governments can provide privileged access to new opportunities in their jurisdiction that help affiliated firms generate 
revenue and profits. As administrative decentralization gives lower-level governments authority over economic policy and development strategy ( $\mathrm{Li}$ et al., 2014), they are able to help their affiliated firms to enhance revenue generation and profitability by protecting their markets and by increasing barriers to entry (Li, Xia, Shapiro, \& Lin, 2018).

Second, lower-level governments in emerging countries such as China provide their affiliated firms with intermediary services and with intelligence and information regarding local markets (Sun et al., 2010). Such intermediary services and intelligence are well aligned with specific idiosyncrasies at the local level, increasing firms' ability to exploit their assets, generate additional revenue and increase profitability by helping them deal with informational disadvantages and institutional uncertainty, decrease transaction and marketing-related costs. As fiscal decentralization in China aligns the interests of lower-level governments with businesses (Yan \& Chang, 2018), it is in the best interest of lower-level governments to support their affiliated firms enhance profitability and thereby increase fiscal revenue and tax income. Hence:

H2: Affiliation with lower levels of government is more effective than affiliation with higher levels of government for enhancing firm profitability.

\subsection{Region-specific IPR efficiency}

Although we expect affiliation with higher-level governments to enhance firms' innovativeness, we further hypothesize that this relationship is stronger in subnational regions with lower IPR efficiency than in regions that feature effective IPR protection. IPR efficiency (how efficiently IPR laws are 
enforced in a jurisdiction) depends on legal, regulatory and other state actors within a jurisdiction (Jandhyala, 2015) and on the confluence of different types and levels of institutions. Particularly in China, IPR efficiency depends on administrative tracks (through government agencies) and judicial tracks (through courts) that may offer diverse prescriptions.

The administrative track is prominent in China as $87 \%$ of the infringement cases in 2006 were resolved through the State Intellectual Property Office (SIPO). IPR laws and judicial systems in developed countries protect all firms. However, the multiplicity of institutions in China leads to spatially uneven institutional development (Kafouros et al., 2015), government intervention (Mbalyohere, Lawtona, Boojihawon, \& Viney, 2017), and regional variations in the enforcement of IPR laws (Kafouros et al., 2015). Hence, whereas the judicial system enforces IPR laws efficiently in certain regions, other regions are characterized by inefficient IPR enforcement.

The theory of institutional polycentrism predicts that when different institutions influence outcomes such as innovation, organizations use stronger institutions to offset the inefficiencies of weaker institutions (Batjargal et al., 2013, Zheng et al., 2015). Applying this logic to our analysis, we posit that because government affiliation and legal institutions substitute one another in protecting innovation (Ostrom et al., 1993), Chinese firms find it more useful to resort to political ties when IPR laws and rules are inefficient or weakly enforced. Empirical evidence supports this view indicating that politically connected Chinese firms are more likely to get favourable verdicts in courts (Firth et al., 2011). By contrast, in regions with lower IPR efficiency, firms gain competitive advantages by using affiliation with higher-level governments. This practice serves as a defence mechanism and as a substitute for inefficient judicial and legal institutions. Because the value-appropriation advantages of 
affiliation with higher-level governments increase when legal institutions are less efficient (Zheng et al., 2015), we expect the marginal usefulness of such affiliation to be stronger in subnational regions with lower IPR efficiency than regions with higher IPR efficiency.

In contrast, the value-appropriation benefits of affiliation with higher-level governments decrease in regions with efficient IPR enforcement because firms can rely on IPR laws and formal institutions that support market transactions and contractual agreements. Because stronger legal institutions reduce the usefulness of non-market strategies (Finchelstein, 2017; Kafouros \& Aliyev, 2016b), the benefits that affiliation with higher-level governments can deliver in regard to IPR protection are weaker. In such situations, despite the advantages of affiliation with higher-level governments, its marginal usefulness for appropriating the value of innovation decreases and its overall effect on firm innovativeness declines. Hence, affiliation with higher-level governments and external IPR institutions substitute one another in influencing a firm's innovation performance:

H3: The effects of affiliation with higher levels of government on firms' innovativeness are stronger in subnational regions with lower IPR efficiency than in subnational regions with higher IPR efficiency.

Building on Hypothesis 2, we further hypothesize that the positive effects of affiliation with lower-level governments on firm profitability are greater in Chinese regions with lower IPR efficiency than in regions with higher IPR efficiency. The reasoning underpinning this hypothesis is the institutional alignment (complementarity) between affiliation with lower-level governments and lower IPR efficiency. Efficient IPR enforcement may benefit firms that innovate, but may adversely affect 
other firms that rely on technological spillovers to generate income (Kafouros \& Buckley, 2008; Kafouros et al., 2015). Inefficient IPR enforcement induces knowledge diffusion (Zhao, 2006) that may enhance the profitability of firms affiliated with lower-level governments by facilitating access to external knowledge and discoveries (Schnaars, 2002). Knowledge diffusion, in turn, increases the stream of high-margin revenues by enabling Chinese firms to capture lower-end users who would not otherwise purchase such outputs (Conner \& Rumelt, 1991).

Affiliation with lower-level governments in China increases the willingness of firms to engage in this behaviour because product imitation can quickly generate profits (Awate et al., 2012), which aligns well with the revenue-related objectives of these governments (Bai et al., 2006; Li et al., 2014). In addition, lower-level governments provide their affiliated firms with preferential regulatory policies (Johnson \& Mitton, 2003), local financial resources (Claessens, Feijen, \& Laeven, 2008), and tailored intermediary services (Sun et al. 2010). These services, along with weak IPR regimes (Berry, 2017; Brander, Cui \& Vertinsky, 2017; Prud'homme, 2019), help firms identify and imitate external opportunities and benefit from spillovers (Cohen \& Levinthal, 1990), increasing therefore their profitability. Due to such institutional complementarities (Ostrom, 2010), we expect the marginal usefulness of affiliation with lower-level governments for increasing firms' profitability to be lower in regions with higher IPR efficiency because of the misalignment between the institutions and firm objectives. Hence:

H4: The effects of affiliation with lower levels of government on firms' profitability are stronger in subnational regions with lower IPR efficiency than in subnational regions with higher IPR efficiency. 


\section{Data and methodology}

\subsection{Sample}

China offers an appropriate setting for testing our framework for several reasons. First, Chinese firms have significantly increased their innovative activities in recent years (Kafouros et al., 2015). For instance, the World Development Indicators from the World Bank indicate that China ranks second in the world in terms of scientific and technical journal articles. Second, the co-existence of the socialist legacy and market institutions in China can explain firms' strategic decisions and performance. The idiosyncratic manner in which many Chinese firms are affiliated with the government provides sufficient variations for testing the hypothesized relationships. Third, Chinese institutions differ significantly across subnational regions (Kafouros et al., 2015), allowing us to examine how such variations change the usefulness of political ties for innovation and non-innovation performance.

Our data cover China's high-tech industries for the period between 2005 and 2007. This was a period when China continued to transit from central planning to a market-oriented system and when the Chinese government introduced the 'indigenous innovation' policy (in 2005). Because of the uncertainty and risks created by this transition, firms had to rely on both institutions and government affiliation to overcome these challenges. As our objective is to compare the effects of different levels of government affiliation, we excluded firms without government affiliation. The firms in the sample span across several 2-digit industries, including medical and pharmaceutical products, special purpose equipment, machinery, transport equipment, electric equipment and machinery, telecommunications, computer and other electronics and instruments. We focused on high-tech industries for two reasons. 
First, because our measure of innovation performance relates to development of new products, we selected industries in which product life cycles are generally short and in which firms compete with new products. Second, IPRs in high-tech industries is particularly important, which allows us to examine the importance of IPR protection and enforcement for government affiliated firms.

Our data were obtained from two sources. The primary source is the Annual Census of Chinese Industrial Firms (ACCIF), compiled by the National Bureau of Statistics of China (NBS). The census provides detailed firm-level information for all firms with annual turnover greater than five million Renminbi (approximately $\$ 680,000$ ). This dataset is one of the most comprehensive firm-level datasets ever compiled by the Chinese statistical office and accounts for approximately $90 \%$ of the total output for most industries. The second data source is the State Intellectual Property Office of China (SIPO) that provides data regarding IPR protection and enforcement for all provinces in China. Because IPR protection and enforcement vary across provinces in China (Kafouros et al., 2015), the province is an appropriate level for examining the contingent value of government affiliation.

We checked the data for missing values, organizational changes (e.g., mergers and acquisitions) and outliers. The final sample includes 18,430 firms that are affiliated with the government at various levels. The sample firms have an average size of 294 employees and represent 7 two-digit high-tech manufacturing sectors throughout 31 provinces, autonomous regions and municipalities of China. To avoid sample selection bias, we also estimate the models after including firms that are not affiliated with government (this increases the size of the sample to 60,612 firms).

Table 1 provides descriptive statistics. In terms of firm distribution by industry, 'Machinery' accounted for the largest share (25.30\%), whilst 'Instruments and meters' is the smallest (5.29\%). The 
average of new product sales share and the average of profitability (ratio of total profits to total assets) across industries and years are both around $7.00 \%$. These figures are reasonably high for government affiliated firms because SOEs are often considered less efficient in converting R\&D inputs into output due to agency problems (Zhou et al., 2017). Yet they are not surprising as high-tech industries feature shorter product life cycles and higher profitability.

(Insert Table 1 about here)

\subsection{Measures}

\subsubsection{Dependent variables}

Innovation performance (or innovativeness) is operationalized as each firm's share of new product sales over total sales. The NBS defines 'new products' as goods that feature stronger functions or have an extended scope of usage due to the adoption of new structures, designs or manufacturing techniques. This measure captures a firm's ability not only to develop but also commercialize innovative products and it is one of the most widely used indicators of innovation performance (Kafouros et al., 2015). Although certain studies use the number of patents to measure innovation, it is less appropriate in the Chinese context not only because numerous innovations are not patented but also because government-controlled firms often apply for patents not necessarily to enhance firm performance but rather to obtain subsidies and advance managers' careers (Boeing, Mueller, \& Sandner, 2016). To capture a firm's Profitability, we followed established practice and operationalized the variable using the return on assets (ROA), which was measured as the ratio of total profits to total assets (Daily, Certo, \& Dalton, 2000).

\subsubsection{Independent variables}


We constructed government affiliation as an ordinal variable for each firm separately using the 'government level' at which each firm is affiliated. Government affiliation differs from government ownership which refers to cases in which government owns a company either wholly or partially. The level of government affiliation does not depend entirely on the degree of government ownership. As shown in the ACCIF database, a private EME may be affiliated with a higher government level (Du \& Girma, 2010) when government has a (low) degree of ownership, whereas an SOE may be affiliated with a lower government level (Wang et al., 2012). Hence, regardless of whether EMEs are government owned, they can be affiliated with different government levels.

The database of ACCIF provides information about whether a firm is affiliated with government and, if so, at which level of government. Following prior research (Wang et al., 2012), we test Hypothesis 1 and Hypothesis 3 by assigning values of 5, 4, 3, 2, and 1 for central government, provincial government, prefectural and city government, county government, and township and village government, respectively. To test Hypothesis 2 and Hypothesis 4, we reverse this operationalization and create a new variable. We thus assign values of 5, 4, 3, 2, and 1 for township and village government, county government, prefectural and city government, provincial government, and central government, respectively.

The above operationalization is consistent with our theoretical discussion and reflects institutional polycentrism, the varying importance of governments at different levels, and thus their differential effect on innovation and profitability. However, like any other ordinal variable, it assumes that there is equal distance between the assigned different numbers. For the above reasons, we also consider an alternative operationalization of government affiliation that uses five separate dummy variables, each of 
which captures whether a firm is affiliated with a particular level of government (the results remained similar; please see the robustness checks section).

Building on research that considered how IPR inefficiency varies across subnational regions (Kafouros et al., 2015), we operationalize IPR inefficiency as one minus the ratio of settled IP infringements to the total number of IP infringements in each region. According to the SIPO, IPR violations include IP infringements and other disputes related to IPR and product counterfeiting. The data for this variable are obtained from SIPO and vary from year to year, capturing how IPR inefficiency evolves over time. Because the legal cases referred to a government agency or court are not necessarily settled in the same year, we used cumulative figures. China uses a 'dual enforcement' system (civil and administrative mechanisms) to address IP infringements. Our measure includes cases through both channels, which more accurately captures how effectively IP infringements are addressed in each region.

A higher ratio of settled IP infringements to the total number of IP infringements in a region reflects a higher level of IPR efficiency. Such a region-specific measure is warranted because our data show that IPR inefficiency varies significantly across Chinese regions. Certain studies have measured IPR enforcement by the existence of relevant laws (e.g., Zhao, 2006). This measure would be highly problematic if applied to China because of the significant discrepancy between written laws and their actual enforcement across regions (Kafouros et al., 2015). Other studies use survey-based perception measures regarding the legal environment to measure IPR efficiency (Faccio, 2006; Sheng et al., 2011), but these measures are subjective and depend on the study participants. 


\subsubsection{Control variables}

Because larger firms can access a larger pool of resources, we control for firm size, measured using the natural logarithm of the total number of employees. In addition, the model includes firm age, measured as the number of years since the firm was founded, to control for the firm's life cycle (i.e., certain firms may become less innovative over time). The high growth rate of the Chinese economy implies that firms might change their strategy and operations even in the short term. This makes firm age an important variable that may influence firm outcomes. Because membership in a business group enables firms to enjoy certain advantages, the model also includes a dummy variable (group affiliation) to control for this effect (equal to 1 for affiliated firms).

Although government ownership can lead to bureaucracy and interference, it may provide innovation-enhancing benefits, such as access to government-controlled technologies. Therefore, we control for government ownership, which is measured as the share of government-owned assets over total assets in a firm. Because foreign ownership provides a firm access to specialized knowledge and resources that might be unavailable to indigenous firms, we control for foreign ownership using the ratio of assets owned by foreign investors to a firm's total assets.

Export-oriented firms are exposed to technological and marketing knowledge. We measure export intensity using the share of a firm's export sales over total sales. Because R\&D increases a firm's ability to obtain and assimilate complementary knowledge from external sources, we include $R \& D$ intensity in the model, measured as total R\&D expenditures divided by total sales. In addition, our model controls for tangible resources, operationalized as fixed assets per employee and slack resources, measured by the debt-to-equity ratio. 
Furthermore, because competition may influence innovation (positively or negatively), we control for industry competition using the measure of one minus the average Lerner's index of individual firms in the 2-digit industry (Hashmi, 2013). The Lerner's index is the difference between the firm's price and its marginal cost, which is identified as the degree of monopoly. Furthermore, inward FDI in an industry influences firm innovativeness and performance through technology spillovers (Dau, 2018). We control for this effect by including industry FDI, measured as the share of foreign assets to total assets for each 2-digit industry. Finally, we introduce dummy variables to account for idiosyncrasies that are associated with industry (7 two-digit industries), region (31 regions) and time (3 years) variations.

\subsubsection{Estimation}

Given that the dependent variable related to firm innovativeness has upper and lower bounds and is censored (it can take zero or positive values), we employ a Tobit model to account for censoring (Greene, 2003) in the innovation models (Models 1-3 of Table 3). Because Tobit models are not defined for fixed effects in panel analysis (Ridge, Ingram, \& Hill, 2017), we can only use random effects method to estimate them. We use the same estimation method (random effects) to estimate the profitability models (Models 4-6) because fixed-effects estimates are less efficient for panels over short periods (Wooldridge, 2009) like ours (3 years). The issue of endogeneity might arise if more innovative firms choose to be affiliated with higher-level government and more profitable firms choose to be affiliated with lower-levels. We reduced potential endogeneity bias by incorporating several variables that account for firm characteristics and by using lagged independent variables. Nevertheless, we used a two-stage instrumental variable (IV) procedure to test the potential endogeneity of the government affiliation variables in both innovation and profitability models. In the first-stage, we regressed all 
potential instruments and all exogenous variables with the government affiliation variable. In the second-stage, we estimated the models by using the predicted values of the possible endogenous variable (Greene, 2003). We used strategic and emerging industries and firm age as IVs for the government affiliation variable for both the innovation and performance equations. We followed the Classification of Strategic and Emerging Industries from the National Bureau of Statistics China (2018) (www.gov.cn/zhengce/2019-01/28/content_5361650.htm) to define strategic and emerging industries. These include 39 ISIC 4-digit industries such as biologicals and biochemical products,_turbines and auxiliary equipment, battery and telecommunications equipment ${ }^{1}$. The variable takes a value of 1 if a firm operates in one of these industries.

Our instruments are appropriate for both theoretical and econometric reasons. First, although many government-affiliated Chinese firms were fully or partially privatized during the economic reform, the Chinese government has maintained control over firms that operate in strategic and emerging industries (Zhu, Tse \& Li, 2019) to foster 'national champions' and improve public provision. However, these firms are not necessarily more innovative or more profitable than their counterparts in other high-tech sectors (Xu \& Wang, 2015). Although certain firms receive government support, this support does not always have the desired effect on a firm's innovativeness and performance. For instance, government officials may find it difficult to control corporate behaviour and subsequently, certain managers may use such funds for purposes other than intended by the government. Hence, we expect strategic and

\footnotetext{
1 The full list of these industries are available from authors.
} 
emerging industries to be highly correlated with government affiliation but not linked to more innovative or better performing firms.

Second, with respect to age, Chinese government's ownership and affiliation reforms determine the longevity of many Chinese firms. For example, the "grasping the large and letting the small go" policy (maintaining government control over larger SOEs and relinquishing control over smaller SOEs) (Naughton, 2007) in combination with the implementation of the Enterprise Bankruptcy Law has created heterogeneity in the lifespan of SOEs by allowing them to continue to run as they are, be merged, be privatized or be shut down. The implications of these changes are reflected on the data. Firm age can explain $10.5 \%$ of the variance in government affiliation (i.e., a strong predictor of the endogenous variable) but only $0.2 \%$ of the variance in new product sales (i.e., it is a weak predictor of the ultimate dependent variable). Thus, firm age is a good instrument for government affiliation.

To assess the exogeneity of the instruments, we followed Bascle (2008) and performed the difference-in-Sargan tests. The results suggest that we cannot reject the null hypothesis that the instruments are exogenous and hence, uncorrelated with the error term (i.e., for the innovation equation, Chi-sq=3.84 and $\mathrm{p}=0.15$; for the profitability equation, Chi-sq=2.96 and $\mathrm{p}=0.23$ ). Moreover, the F-statistics from the first stage of the IV process confirm that the instruments are relevant and strong. Furthermore, the Hausman test (Hausman, 1978) shows that the null hypothesis (the variation between the pooled Tobit estimator and the IV Tobit estimator is not systematic) is not rejected (i.e., for the innovation equation, Chi-sq=56.96 and $\mathrm{p}=0.26$; for the profitability equation, Chi-sq=61.54 and $\mathrm{p}=0.15$ ). This indicates that government affiliation is not endogenous for both the innovation and profitability equations. 
Following common practice, we mean-centred the firm-specific variables and moderators (IPR inefficiency only) before creating the interaction terms and used the residual centering procedure to reduce multicollinearity concerns. In addition, we lagged the independent variables and interactions by one year. Finally, we used Huber-White's robust standard errors to address the possible threat of heteroskedasticity (White, 1980).

\section{Results}

\subsection{Main results}

Table 2 presents the mean values, standard deviations and correlations for the variables. The variance inflation factors (VIFs) range from 1.00 to 1.96 and the average value is less than 10, which indicates that multicollinearity did not have an undue influence on the estimates. Table 3 presents the main results. Models 1-3 and 4-6 focus on innovation and profitability, respectively. The coefficient of government affiliation in Models 2 and 3 is positive and statistically significant. These results support Hypothesis 1 which suggests that affiliation with higher-level governments enhances firm innovativeness.

\section{(INSERT TABLES 2 and 3 ABOUT HERE)}

Models 5-6 show that the coefficient of government affiliation (defined in reversed order) is positive and statistically significant. This finding corroborates Hypothesis 2 which suggests that affiliation with lower government levels enhances profitability. To interpret the economic significance of these findings, we followed standard practice (Hoetker, 2007) and estimated the marginal effects of government affiliation at the mean and one standard deviation above and below the mean (while keeping 
other variables at their mean). This analysis indicates that a standard deviation above the mean value of government affiliation enhances innovation performance by 1.26 percentage points. With regards to the profitability estimates, a standard deviation below the mean of government affiliation increases EMEs' profitability by 2.52 percentage points.

Furthermore, Models 2-3 show that IPR inefficiency hampers innovation performance which is in line with the innovation literature. In contrast, Models 5 and 6 show that IPR inefficiency enhances profitability. This result may appear surprising but it is consistent with the view that weaker IPR protection allows firms to access knowledge spillovers and generate income (Schnaars, 2002; Kafouros et al., 2015). These results are also consistent with those concerning $R \& D$ (which are significant in Models 1-3) but they are insignificant in Models 4-6.

Model 3 shows that the interaction term between government affiliation and IPR inefficiency is positive and significant. This result corroborates Hypothesis 3 which states that IPR inefficiency positively moderates the effects of affiliation with higher-level government on innovativeness. Model 6 shows that the interaction term between government affiliation (defined in reverse order) and IPR inefficiency is positive but statistically insignificant. This result does not support Hypothesis 4 that suggests that the effects of affiliation with lower levels of government on firms' profitability are stronger in subnational regions with lower IPR efficiency. A tentative explanation for this finding is that although there is alignment between lower-level governments and the institutional prescriptions of a weaker IPR regime which enable firms to get access to external knowledge spillovers (Schnaars, 2002), firms affiliated with lower-level governments may lack the absorptive capacity to reap such spillovers and enhance profitability due to limited experience and exposure to international competition. 
It is worth noting that government ownership is not significant in Model 1 but becomes significant in Models 2 and 3 when government affiliation is added. A tentative explanation is that government ownership in Model 1 captures the effects of ownership that is held by both higher and lower government levels. Hence the mixed effects of both forces that enhance innovation and profitability. This variable is insignificant in Model 1 when the effect of government affiliation is not controlled because none of two 'forces' dominates the effect on innovation. It becomes significant in Models 2 and 3 when the effect of government affiliation is controlled for because government ownership in both models captures the effect of government ownership in which higher government levels either have larger share or take control over key decision-making.

\subsection{Robustness checks}

First, we re-estimated all models with the dependent variable defined as new product sales, i.e., log $(1+$ new product sales), rather than the share of new product sales to total sales (because data for new product sales are truncated to zero) and control for the effect of $\log$ (total sales). The results in Section A of Table 4 are highly consistent with the main results (Hypotheses 1-3 are supported but Hypothesis 4 is not). Second, we have examined whether there is a curvilinear relationship (U-shape or inverse U-shape) between government affiliation and innovation performance and between government affiliation and profitability by adding a squared term of government affiliation. The results of this analysis indicate that a $\mathrm{U}$-shape (or inverse $\mathrm{U}$-shape) relationship is absent in the data.

(INSERT TABLE 4 ABOUT HERE) 
Third, we re-estimated all models by defining government affiliation as a dichotomous $0 / 1$ measure that captures whether a firm is affiliated with a higher level of government (i.e. central and provincial government) or with a lower level. Section B of Table 4 show that the hypothesized results remain qualitatively unchanged (though the level of significance for the coefficients related to Hypotheses 2 and 3 reduces). Similar results are also obtained when we used a dummy that is equal to 1 if the firm is affiliated with central government. In addition, we experimented by using three dummies, i.e. affiliation with the central government or the province government (high affiliation level), affiliation with the city government (middle affiliation level), and affiliation with the county government or the town government (low affiliation level), respectively. The results pertaining to the hypotheses remain qualitatively unchanged ${ }^{2}$.

Fourth, we defined IPR inefficiency as the number of cases received by the court in each province weighted by the population of the province (in a reversed order) (Li, Meng, Wang, \& Zhou, 2008). The results in Section $\mathrm{C}$ of Table 4 show that Hypotheses 1 to 3 are supported, whilst Hypothesis 4 remains unsupported. Fifth, all firms in our sample are affiliated with government, which may lead to sample selection bias. We therefore estimated our models using a sample that also includes firms that are not affiliated with government (the total number of firms becomes 60,612 firms). Once again, the results reported in section D of Table 4 support Hypotheses 1-3 but not Hypothesis 4.

Finally, we extended the data period to include 2008 and 2009 when the global economy was hit by the financial crisis. Due to data constraints for these two years, we had to drop several control variables

\footnotetext{
${ }^{2}$ The results using the latter two approaches are available from authors.
} 
including R\&D intensity, government ownership, foreign ownership, and tangible resources. Section E of Table 4 shows that the results remain qualitatively the same to those reported in Table 3 . It also indicates that our key results are robust to the models excluding $R \& D$ intensity, government ownership, foreign ownership, and tangible resources. Overall, these results are highly consistent with the main results and support the premise that different levels of government affect firm innovativeness and profitability differently.

\section{Discussion and conclusion}

\subsection{Theoretical contributions}

First, the IB literature has examined how institutions affect EMEs' innovativeness (Boeing et al., 2016; Piperopoulos, Wu, \& Wang, 2018; Xie \& Li, 2018) and how governments help firms create value (Okhmatovskiy, 2010; Zhou et al., 2017). However, little research has focused on affiliation with different hierarchical ranks of government and on how different levels of affiliation influence firm innovation vis-à-vis firm profitability. Drawing on the theory of institutional polycentrism, our framework complements prior institutional explanations (e.g., Kafouros \& Aliyev, 2016) by advancing the view that variations in firm innovativeness and profitability are driven by the level at which EMEs are affiliated with government (rather than by the existence of such ties).

A central tenet of our framework is that because different government levels have different priorities and exert different institutional pressures (Bai et al., 2006; Sun et al., 2010), they influence the willingness and ability of firms to innovate or become profitable differently. While affiliation with higher government levels is more advantageous for firm innovativeness, affiliation with lower 
government levels is more beneficial for firm profitability. Our analysis therefore moves beyond the view that affiliation with higher government levels is always preferable (Wang et al., 2012) and offers a more nuanced explanation of when and how political ties create value for firms (Lester et al., 2008).

Second, our framework clarifies the role of location-specific institutional contingencies and how external institutions complement or substitute the political ties of the firm. By showing that firms are affected by IPR protection differently depending on the level at which they are affiliated with government, our analysis demonstrates how the value of non-market strategies (such as government ties) is affected by legal institutions (Kafouros \& Aliyev, 2016a). It also shows that firms affiliated with higher-level governments do not always need strong IPR regimes to mitigate hazards (Paik \& Zhu, 2016). Affiliation buffers firms by serving as a compensatory mechanism for weak IPR institutions (Zheng et al., 2015). The findings also support the notion of institutional substitution (Batjargal et al., 2013; Ostrom et al., 1993) and explain how firms use alternative institutions (i.e. government affiliation) to compensate for IPR laws that are less effective. Although weak IPR protection is often considered as an impediment to innovation (Teece, 1986), it seems that government affiliation helps EMEs reap the benefits of their technological efforts when IPR protection is weak.

Third, we contribute to the literature on the role of government (Sheng et al., 2011; Wang et al., 2012; Zhou et al., 2017) by demonstrating that governments support their affiliated firms in different ways. It has recently been suggested that the role of government in driving innovation declines as market mechanisms evolve (Sun \& Liu, 2014; Zhou et al., 2017). Although our findings do not contradict this premise, they indicate that ties with higher-level governments remain valuable for creating and protecting innovation, particularly in regions with weak IPR regimes. This finding also enriches prior 
work on the role of subnational institutions (Hong et al., 2015; Kafouros et al., 2015; Zhou et al., 2017) by showing how government affiliation compensates for inherent disadvantages in regions that feature ineffective IPR institutions.

Finally, our study contributes to the literature on state capitalism. The findings that different levels of government affect firm innovation and profitability differently suggest that new forms of state capitalism in the wake of institutional and market-based reforms change the strategic objectives and behaviour of firms. These findings differ from conceptualizations that assume that all SOEs are used as a policy instrument for achieving similar goals (Grosman, Okhmatovskiy, \& Wright, 2016; Musacchio, Lazzarini, \& Aguilera, 2015; Wood \& Wright, 2015). They therefore extend studies that focus on country-level state capitalism and its impact on national economies (Bruton, Peng, Ahlstrom, Stan, \& Xu, 2015; Grosman, Okhmatovskiy, \& Wright, 2016; Musacchio, Lazzarini, \& Aguilera, 2015; Wood \& Wright, 2015) by theoretically mapping the effects of state capitalism to firm-level outcomes ( $\mathrm{Li}$, Cui, $\& \mathrm{Lu}, 2014)$ and by explaining how region-specific institutions interact with certain forms of state capitalism to affect firm outcomes.

\subsection{Implications for managers and policy makers}

First, although many prior studies merely suggest that managers should establish connections with government, our analysis emphasizes that managers should consider at which level such connections are built. When managers devise nonmarket strategies, they should carefully consider how their decisions fit with the firm's strategic priorities. Although prior literature and the press typically view affiliation with government as an impediment to firms' innovation and profitability (e.g., Zhou et al., 2017), we 
show that a non-market strategy that focuses on establishing connections with higher government levels is particularly advantageous when firms prioritize innovation. However, managers should not assume that higher level connections are preferable to lower level ones. Affiliation with lower levels of governments is particularly beneficial when managers aim to increase profitability.

Second, when managers devise nonmarket strategies, they should also know that the effectiveness and advantages of such strategies depend on the context and location in which their firms operate. When firms want to innovate in regions with ineffective IPR enforcement, they should try to establish connections with higher-level governments as these can help them overcome the challenges that impede innovation in such locations. Although firms cannot easily change the location in which they already operate, such considerations might influence potential target locations for expansion. Overall, developing nonmarket strategies in a given institutional environment (Xu \& Meyer, 2013) requires careful consideration of how political ties substitute for certain institutions (and vice versa). To increase the effectiveness of nonmarket strategies, EME managers should not be overly concerned with the level of government affiliation. Rather, they should understand the objectives for different levels of government and ensure that these objectives align with their own priorities (innovativeness or profitability).

Furthermore, the Chinese government has long tried to improve the innovation capabilities of the nation. The findings of this study have implications for policy makers by emphasizing the regional dimension and the different levels of government affiliation. Although policy makers attempt to carefully design institutional mechanism to help firms innovate, it seems that only affiliation with government at higher levels is effective in helping firms overcome institutional voids and in enhancing 
their innovativeness. The evidence showing that different levels of government provide different benefits highlights how important the consideration of institutional polycentricism is in policy making. It also implies that different levels of governments must learn from each other and try to align and balance their goals to increase cohesion and avoid frictions.

\subsection{Limitations and future research}

First, our predictions are applicable to emerging countries that exhibit polycentric institutions, government intervention, the separation of power between executive and legislative authorities, and concurrent appointments to business, government and legislative positions (Choi et al., 2015; Zheng et al., 2015). Yet, as state capitalism is idiosyncratic to each emerging country (Kafouros and Aliyev, 2016a; Yergen \& Stanislaw, 2002), a theoretically useful extension would be to adopt a comparative approach and examine such relationships across emerging countries. For instance, although state control over firms is prevalent in countries such as Malaysia, Saudi Arabia and Algeria, it differs from that of China which is rooted in the former central planning system. Future research could therefore help us advance theory on how firms across emerging countries and contexts are connected to different levels of governments, and how these connections in turn influence innovation and non-innovation performance outcomes.

Second, our analysis has shown how location- and context-specific contingencies change the effects of affiliation with governments. Examining contingencies other than those considered in this study could be another effective way to understand how the roles of the state and government change under different circumstances. For example, it would be useful to investigate how the influence of different 
levels of governments are affected by idiosyncrasies pertaining to firm-specific capabilities (Wang et al., 2012). Furthermore, although we focused on product innovation, distinguishing between different types of innovations (managerial, product and process; incremental and radical) would be another opportunity for future research. Finally, data availability limits our ability to examine how relationships with government evolve over time. Longitudinal data for longer periods can enable future studies to advance research on state capitalism by examining how temporal dimensions (e.g., see Hashai, Kafouros \& Buckley, 2018), such as the maturity of political ties, shape relationships between firms and governments and in turn affect certain outcomes. 


\section{References}

Ahuja, G., \& Yayavaram, S. (2011). Explaining influence rents: The case for an institutions-based view of strategy. Organization Science, 22(6):1631-1652.

Bai, J., \& Li, J. (2011). Regional innovation efficiency in China: the role of local government. Innovation: Management, Policy and Practice, 13(2):142-153.

Bai, C., Lu, J., \& Tao, Z. (2006). The multitask theory of state enterprise reform: empirical evidence from China. American Economic Review, 96(2):353-357.

Bascle, G. (2008). Controlling for endogeneity with instrumental variables in strategic management research. Strategic Organization, 6(3): 285-327.

Batjargal, B., Hitt, M.A., Tsui, A. S., Arregle, J.L., Webb, J.W., \& Miller, T.L. (2013). Institutional polycentrism, entrepreneurs' social networks, and new venture growth. Academy of Management Journal, 56(4):1024-1049.

Berry, H. (2017). Managing valuable knowledge in weak IP protection countries, Journal of International Business Studies, 48(7): 787-807.

Boeing, P., Mueller, E., \& Sandner, P. (2016). China's R\&D explosion-Analyzing productivity effects across ownership types and over time. Research Policy, 45(1):159-176.

Boisot, M. M., \& Meyer, M. W. (2008). Which way through the open door? Reflections on the internationalization of Chinese firms. Management \& Organization Review, 4(3): 349-365.

Brander, J. A., Cui, V., \& Vertinsky, I. (2017). China and intellectual property rights: A challenge to the rule of law. Journal of International Business Studies, 48(7): 908-921.

Bruton, G. D., Peng, M. W., Ahlstrom, D., Stan, C., \& Xu, K. (2015). State-owned enterprises around the world as hybrid organizations. The Academy of Management Perspectives, 29(1), 92-114.

Buddelmeyer, H., Jensen, P. H., \& Webster, E. (2009). Innovation and the determinants of firm survival. Oxford Economic Paper, 62(2): 261-285.

Choi, S. B., Lee, S.H., \& Williams, C. (2011). Ownership and firm innovation in a transition economy: Evidence from China. Research Policy, 40(3):411-452. 
Choi, S. J., Jia, N., \& Lu, J. (2015). The structure of political institutions and effectiveness of corporate political lobbying. Organization Science, 26(1):158-179.

Claessens, S., Feijen, E., \& Laeven, L. (2008). Political connections and preferential access to finance: The role of campaign contributions. Journal of Financial Economic, 88(3): 554-580.

Clegg, L. J., Voss, H., \& Tardios, J. A. (2018). The autocratic advantage: Internationalization of state-owned multinationals. Journal of World Business. 53(5): 668-681.

Cohen, W. M., \& Levinthal, D. A. (1990). Absorptive capacity: A new perspective on learning and innovation. Administrative Science Quarterly, 35(1):128-152.

Conner, K., \& Rumelt, R. (1991). Software piracy: An analysis of protection strategies. Management Science, 37(2):125-139.

Crossan, M. M., \& Apaydin, M. (2010). A multi-dimensional framework of organizational innovation: a systematic review of the literature. Journal of Management Studies, 47(6): 1154-1191.

Cuervo-Cazurra, A., Inkpen, A., Musacchio, A., \& Ramaswamy, K. (2014). Governments as owners: state owned multinational companies. Journal of International Business Studies, 45(9): 919-942.

Cui, L., \& Jiang, F. (2012). State ownership effect on firms' FDI ownership decisions under institutional pressure: A study of Chinese outward-investing firms. Journal of International Business Studies, 43(3): 264-284.

Daily, C. M., Certo, S. T., \& Dalton, D. R. (2000). Research notes and communications: International experience in the executive suite: the path to prosperity. Strategic Management Journal, 21(4): $515-523$.

Dau, A. L. (2018). Contextualizing international learning: The moderating effects of mode of entry \& subsidiary networks on the relationship between reforms \& profitability. Journal of World Business, 53: 403-414.

Du, J., \& Girma, S. (2010). Red capitalists: Political behavior and growth and survival of start-ups in China. Kyklos, 63(4): 530-545.

Faccio, M., McConnell, J. J., \& Masulis, W. R. (2006). Political connections and corporate bailouts. Journal of Finance, 61(6): 2597-2635. 
Fernández-Méndeza, L., García-Canal, E., \& Guillénc, M. F. (2018). Domestic political connections and international expansion: It's not only 'who you know' that matters. Journal of World Business, 53(5): 695-711.

Finchelstein, D. (2017). The role of the State in the internationalization of Latin American firms. Journal of World Business, 52(4): 578-590.

Firth, M., Rui, O. M., \& Wu, W. (2011). The effects of political connections and state ownership on corporate litigation in China. The Journal of Law \& Economics, 54(3):573-607.

Frye, T., \& Shleifer, A. (1997). The invisible hand and the grabbing hand. The American Economic Review, 87(2):354-358.

Gavetti, G., Greve, H. R., Levinthal, D. A., \& Ocasio, W. (2012). The behavioral theory of the firm: Assessment and prospects. Academy of Management Annals, 6(1): 1-10.

Girma, S., \& Du, J. (2010). Red capitalists: Political connections and firm performance in China. Kyklos, 63: 530-545.

Greene, W. H. (2003). Econometric Analysis (Pearson Education, New Jersey).

Grosman, A., Okhmatovskiy, I., \& Wright, M. (2016). State control and corporate governance in transition economies: 25 years on from 1989, Corporate Governance: An International Review, 24(3): 200-221.

Hashai, N., Kafouros, M., \& Buckley, P. J. (2018). The performance implications of speed, regularity, and duration in alliance portfolio expansion. Journal of Management, 44(2), 707-731.

Hashmi, A. R. 2013. Competition and innovation: The inverted-U relationship revisited. Review of Economics and Statistics, 95(5):1653-1668.

Hausman, J. A. (1978). Specification tests in econometrics. Econometrica, 46(6):1251-1271.

Hillman, A. J., Zardkoohi, A., \& Bierman, L. (1999). Corporate political strategies and firm performance: Indications of firm-specific benefits from personal service in the US government. Strategic Management Journal, 20(1): 67-81.

Hoetker, G. (2007). The use of logit and probit models in strategic management research: Critical issues. Strategic Management Journal, 28(4): 331-343. 
Hong, J., Wang, C., \& Kafouros, M. (2015). The role of the state in explaining the internationalization of emerging market enterprises. British Journal of Management, 26(1): 45-62.

Hoskisson, R.E., Wright, M., Filatotchev, I., \& Peng, M.W. (2013). Emerging multinationals from mid-range economies: the influence of institutions and factor markets. Journal of Management Studies, 50(7): 1295-1321.

Jandhyala, S. (2015). International and domestic dynamics of intellectual property protection. Journal of World Business, 50(2): 284-293.

Johnson, S., \& Mitton, T. (2003). Gronyism and capital controls: Evidence from Malaysia. Journal of Financial Economics, 67(2): 351-382.

Kafouros, M. I., \& Buckley, P. J. (2008). Under what conditions do firms benefit from the research efforts of other organizations?. Research Policy, 37(2), 225-239.

Kafouros, M., Wang, C., Piperopoulos., P., \& Zhang, M. (2015). Academic collaborations and firm innovation performance in China: The role of region-specific institutions. Research Policy, 44(3): 803-817.

Kafouros, M., \& Aliyev, M. (2016a). Institutions and foreign subsidiary growth in transition economies: The role of intangible assets and capabilities. Journal of Management Studies, 53(4): 580-607.

Kafouros, M., \& Aliyev, M. (2016b). Institutional development and firm profitability in transition economies. Journal of World Business, 51(3), 369-378.

Khwaja, A. I., \& Mian, A. (2005). Do lenders favor politically connected firms? Rent provision in an emerging financial market. The Quarterly Journal of Economics, 120(4), 1371-1411.

Krammer, S M. S., \& Jiménez, A. (2019). Do political connections matter for firm innovation? Evidence from emerging markets in Central Asia and Eastern Europe. Technological Forecasting and Social Change, article in press.

Jin, H., Qian, Y., \& Weingast, B. (2005). Regional decentralization and fiscal incentives: Federalism, Chinese style. Journal of Public Economics, 89(9-10):1719-1742. 
Lester, R. H., Hillman, A., Zardkoohi, A., \& Cannella Jr., A. A. (2008). Former government officials as outside directors: the role of human and social capital. Academy of Management Journal, 51(5): 999-1013.

Li, J., Chen, D., \& Shapiro, D. M. (2010). Product innovations in emerging economies: The role of foreign knowledge access channels and internal efforts in Chinese firms. Management and Organization Review, 6(2): 243-266.

Li, M. H, Cui, L., \& Lu, J. (2014). Varieties in state capitalism: Outward FDI strategies of central and local state-owned enterprises from emerging economy countries. Journal of International Business Studies, 45(8): 980-1004.

Li, H., Meng, L., Wang, Q., \& Zhou, L. A. (2008). Political connections, financing and firm performance: Evidence from Chinese private firms. Journal of Development Economics, 87(2): 283-299.

Li, S., Park, S. H., \& Li, S. (2004). The great leap forward: The transition from relation-based governance to rule-based governance. Organization Dynamics, 33(1): 63-78.

Li, W., \& Putterman, L. (2008). Reforming China's SOEs: An overview. Comparative Economic Studies 50(3): 353-380.

Li, J., Xia, J., Shapiro, D., \& Lin, Z. (2018). Institutional compatibility and the internationalization of Chinese SOEs: The moderating role of home subnational institutions. Journal of World Business, 53(5): 641-652.

Liu, H., Yang, J. Y., \& Augustine, D. (2019). Political ties and firm performance: The effects of proself and prosocial engagement and institutional development. Strategic Management Journal, 8(3): 471-502.

Luo, Y., \& Bu, J. (2018). Contextualizing international strategy by emerging market firms: A composition-based approach. Journal of World Business, 53: 337-355.

Ivus, O. (2015). Does stronger patent protection increase export variety? Evidence from U.S. product-level data. Journal of International Business Studies, 46(6): 724-731. 
Mbalyohere, C., Lawtona, T., Boojihawon, R., \& Viney, H. (2017). Corporate political activity and location-based advantage: MNE responses to institutional transformation in Uganda's electricity industry. Journal of World Business, 52(6): 743-759.

McCann, P., Oxley, L. (2012). Innovation, entrepreneurship, geography and growth. Journal of Economic Surveys, 26(3), 373-376.

Meyer, K. E., \& Peng, M. W. (2016). Theoretical Foundations of Emerging Economy Research. Journal of International Business Studies, 47(1): 3 - 22.

Musacchio, A., \& Lazzarini, S. G. (2014). Reinventing state capitalism. Harvard University Press.

Musacchio, A., Lazzarini, S., \& Aguilera, R. (2015). New varieties of state capitalism: Strategic and governance implications. The Academy of Management Perspectives, 29(1), 115-131.

National Bureau of Statistics of China. (2001). Large corporations of China. China Statistics Press, Beijing, CN.

National Bureau of Statistics of China. (2018). Classification of Strategic and Emerging Industries. www.gov.cn/zhengce/2019-01/28/content_5361650.htm.

Naughton, B. (2007). The Chinese Economy: Transitions and Growth (Cambridge, MA: MIT Press, 2007), 301-302.

OECD (2005). Oslo Manual, Guidelines for Collecting and Interpreting Innovation Data. OECD Publishing, Paris.

Okhmatovskiy, I. (2010). Performance implications of ties to the government and SOEs: A political embeddedness perspective. Journal of Management Studies, 47(6):1020-1047.

Ostrom, E. (2010). Beyond markets and states: polycentric governance of complex economic systems. Transnational Corporations Review, 2(2):1-12.

Ostrom, E. (2011). Background on the institutional analysis and development framework. Policy Studies Journal, 39(1):7-27.

Ostrom, E., Schroeder., L., \& Wynne, L. (1993). Institutional Incentives and Sustainable Development: infrastructure policies in perspective (West View, Boulder, CO).

Paik, Y., \& Zhu, F. (2016). The impact of patent wars on firm strategy: Evidence from the global smartphone industry. Organization Science, 27(6): 1397-1416. 
Peng, M. W., \& Luo, Y. (2000). Managerial ties and firm performance in a transition economy: the nature of a micro-macro link. Academy of Management Journal, 43(3):486-501.

Piperopoulos, P., Wu, J., \& Wang, C. (2018). Outward FDI, location choices, and innovation performance of emerging market enterprises. Research Policy, 47(1): 232-240.

Potter, P. B. (1999). The Chinese legal system: Continuing commitment to the primacy of state power. China Quarterly, 159: 673-683.

Prud'homme, D. (2019). Re-conceptualizing intellectual property regimes in international business research: Foreign-friendliness paradoxes facing MNCs in China. Journal of World Business, 54(4): 399-419.

Ridge, J. W., Ingram, A., \& Hill, A. D. (2017). Beyond lobbying expenditures: How lobbying breadth and political connectedness affect firm outcomes. Academy of Management Journal, 60(3):1138-1163.

Schnaars, S. (2002). Managing imitation strategies: How later entrants seize markets from pioneers (The Free Press, New York).

Scott, W. R. (1995). Institutions and Organizations (Sage, Thousand Oaks, CA).

Sheng, S., Zhou, K., \& Li, J. (2011). The effects of business and political ties on firm performance: evidence from China. Journal of Marketing, 75(1):1-15.

Shi, W., Markoczy, L., \& Stan, C. V. (2014). The continuing importance of political ties in China. The Academy of Management Perspectives 28(1): 57-75.

Singh, S., Darwish, TK., Wood, G., \& Mohamed, AF. (2017). Institutions, complementarity, human resource management and performance in a South-East Asian Petrostate: the case of Brunei. International Journal of Human Resource Management, 28 (18): 2538-2569.

Soh, P. H., \& Yu, J. (2010). Institutional environment and complementary assets: Business strategy in China's 3G development. Asia Pacific Journal of Management, 27(4): 647-675.

Sun Y., \& F. Liu (2014). New trends in Chinese innovation policies since 2009-A system framework of policy analysis. International Journal of Technology Management, 65(1): 6-23. 
Sun, P., Mellahi, K., \& Thun, E. (2010). The dynamic value of MNE political embeddedness: The case of the Chinese automobile industry. Journal of International Business Studies, 41(7):1161-1182.

Sun, P., Mellahi, K., \& Wright, M. (2012). The contingent value of corporate political ties. Academy of Management Perspectives. 26(3): 68-82.

Sun, P., Mellahi, K., Wright, M., \& Xu, H. (2015). Political tie heterogeneity and the impact of adverse shocks on firm value. Journal of Management Studies, 52(8):1036-1063.

Sun, P., Hu, H. W., \& Hillman, A. J. (2015). The dark side of board political capital: Enabling blockholder rent appropriation. Academy of Management Journal, 59(5):1801-1822.

Teagarden, B. M., Glinow, A. V., \& Mellahi, K. (2018). Contextualizing international business research: Enhancing rigor and relevance. Journal of World Business, 53: 303-306.

Teece, D. J. (1986). Profiting from technological innovation: implications for integration, collaboration, licensing and public policy. Research Policy, 15(6): 285-305.

Tian, G. (2000). Property rights and the nature of Chinese collective enterprises. Journal of Comparative Economics, 28(2): 247-268.

Tihanyi, L., Aguilera, R. V., Heugens, P., van Essen, M., Sauerwald, S., Duran, P., \& Turturea, R. (2019). State Ownership and Political Connections. Journal of Management, forthcoming.

Walder, A. G. (2004). The party elite and China's trajectory of change. China: An International Journal, 2(2):189-209.

Wang, C., Hong. J., Kafouros, M., \& Wright, M. (2012). Exploring the role of government involvement in outward direct investment from emerging economies. Journal of International Business Studies, 43(7):655-676.

Wang, D., Sutherland, D., Ning, L., Wang, Y., \& Pan, X. (2018). Exploring the influence of political connections and managerial overconfidence on R\&D intensity in China's large-scale private sector firms. Technovation, 69, 40-53.

White, H. (1980). A heteroscedasticity consistent covariance matrix estimator and a direct test for heteroscedasticity. Econometrica, 48(4): 817-838. 
Wood, G., \& Wright, M. (2015). Corporations and new statism: Trends and research priorities. The Academy of Management Perspectives, 29(2): 271-286.

Wooldridge, M. (2009). An Introduction to Multiagent Systems (John Wiley \& Sons, West Sussex).

Xie, Z. \& Li, J.T. 2018. Exporting and innovating among emerging market firms: The moderating role of institutional development. Journal of International Business Studies, 49(2): 222-245.

Xu, D., Lu, J. W., \& Gu, Q. 2014. Organizational forms and multi-population dynamics: Economic transition in China. Administrative Science Quarterly, 59(3):517 -547.

Xu, D., \& Meyer, K. E. (2013). Linking theory and context: 'Strategy research in emerging economies' after Wright et al. (2005). Journal of Management Studies, 50(7):1322-1346.

Xu, D., \& Wang, J. (2015). Strategic emerging industries in China: Literature review and research prospect. American Journal of Industrial and Business Management, 5(7): 486-506.

Yan, Z., \& Chang, S. J. (2018). The contingent effects of political strategies on firm performance: A political network perspective. Strategic Management Journal, 39: 2152-2177.

Yergen, D. \& Stanislaw, J. (2002). The commanding heights: The battle for the world economy. New York: Simon \& Schuster. Zhao, M. (2006). Conducting R\&D in countries with weak intellectual property rights protection. Management Science, 52(8):1185-1199.

Zhang, M., Qi, Y., Wang, Z., Zhao, X., \& Paware, K. S. (2019). Effects of business and political ties on product innovation performance: Evidence from China and India. Technovation, 80-81: 30-39.

Zheng, W., Singh, K., \& Mitchell, W. (2015). Buffering and enabling: The relationship of interlocking political ties with firm survival and sales growth. Strategic Management Journal, 36(11):1615-1636.

Zhou, K. Z., Gao, G. Y., \& Zhao, H. (2017). State ownership and firm innovation in China: An integrated view of institutional and efficiency logics. Administrative Science Quarterly, 62(2): 375-404.

Zhu, J. J., Tse, C. H., and Li, X. (2019). Unfolding China's state-owned corporate empires and mitigating agency hazards: Effects of foreign investments and innovativeness. Journal of World Business, 564(3): 191-212. 
Government ties and firm innovativeness 45 


\section{TABLES}

Table 1 Sample Distribution and Statistics $(\mathrm{N}=18,430)$

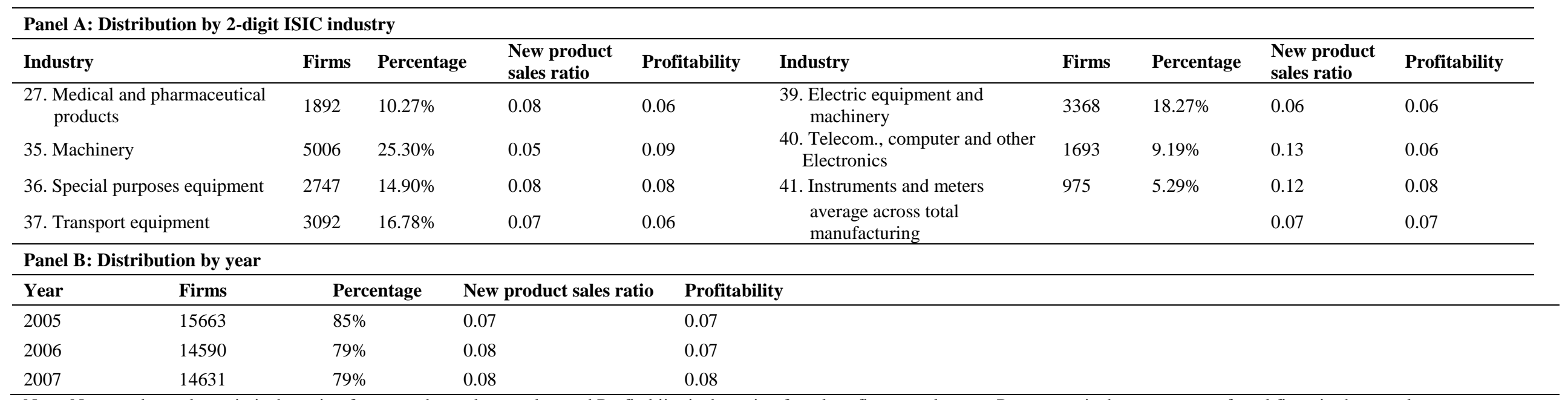

Note: New product sales ratio is the ratio of new product sales to sales, and Profitabiity is the ratio of total profits to total assets. Percentage is the percentage of total firms in the sample. 
Table 2 Descriptive statistics and correlation matrix of variables

\begin{tabular}{|c|c|c|c|c|c|c|c|c|c|c|c|c|c|c|c|c|c|}
\hline & mean & s.d. & 1 & 2 & 3 & 4 & 5 & 6 & 7 & 8 & 9 & 10 & 11 & 12 & 13 & 14 & 15 \\
\hline 1 Innovation performance & 0.07 & 0.20 & 1.00 & & & & & & & & & & & & & & \\
\hline 2 Profitability & 0.07 & 0.46 & $-0.03^{* *}$ & 1.00 & & & & & & & & & & & & & \\
\hline 3 Gov. affiliation & 2.33 & 1.26 & $0.21^{* *}$ & $-0.09^{* *}$ & 1.00 & & & & & & & & & & & & \\
\hline 4 IPR inefficiency & 0.10 & 0.07 & $-0.05^{* *}$ & -0.00 & $-0.02^{* *}$ & 1.00 & & & & & & & & & & & \\
\hline 5 Firm size & 5.02 & 1.10 & $0.20^{* *}$ & $-0.03^{* *}$ & $0.29^{* *}$ & $0.04^{* *}$ & 1.00 & & & & & & & & & & \\
\hline 6 Firm age & 15.32 & 15.21 & $0.08^{* * *}$ & $-0.04^{* *}$ & $0.25^{* *}$ & $0.03^{* *}$ & $0.31^{* *}$ & 1.00 & & & & & & & & & \\
\hline 7 Group affiliation & 0.06 & 0.23 & $0.08^{* *}$ & $-0.03^{* *}$ & $0.17^{* *}$ & $0.02^{* *}$ & $0.24^{* *}$ & $0.20^{* *}$ & 1.00 & & & & & & & & \\
\hline 8 Government ownership & 0.13 & 0.31 & $0.05^{* *}$ & $-0.06^{* *}$ & $0.39^{* *}$ & $0.03^{* *}$ & $0.18^{* *}$ & $0.30^{* *}$ & $0.14^{* *}$ & 1.00 & & & & & & & \\
\hline 9 Foreign ownership & 0.06 & 0.21 & $-0.01^{* *}$ & $0.01^{*}$ & $0.03^{* *}$ & $-0.05^{* *}$ & $0.03^{* *}$ & $-0.13^{* *}$ & $-0.05^{* *}$ & $-0.08^{* *}$ & 1.00 & & & & & & \\
\hline 10 Export intensity & 0.09 & 0.23 & $0.06^{* *}$ & $-0.01^{* *}$ & $-0.04^{* *}$ & $-0.02^{* *}$ & $0.15^{* *}$ & $-0.05^{* *}$ & $-0.01^{\dagger}$ & $-0.06^{* *}$ & $0.27^{* *}$ & 1.00 & & & & & \\
\hline 11 R\&D intensity & 0.01 & 0.14 & $0.04^{* *}$ & $-0.02^{* *}$ & $0.05^{* *}$ & $-0.01^{* *}$ & $0.02^{* *}$ & 0.01 & 0.01 & 0.01 & -0.01 & -0.01 & 1.00 & & & & \\
\hline 12 Tangible resources & 96.87 & 284.88 & $0.02^{* *}$ & $-0.01^{* *}$ & $0.06^{* *}$ & $-0.02^{* *}$ & $-0.06^{* *}$ & -0.01 & $0.02^{* *}$ & $0.04^{* *}$ & $0.06^{* *}$ & $-0.01^{\dagger}$ & 0.01 & 1.00 & & & \\
\hline 13 Slack resources & 3.33 & 89.06 & 0.00 & $0.02^{* *}$ & $-0.01^{* *}$ & 0.01 & $-0.01^{* *}$ & $-0.01^{* *}$ & -0.01 & $-0.01^{*}$ & 0.00 & -0.00 & -0.00 & 0.00 & 1.00 & & \\
\hline 14 Industry competition & 0.97 & 0.05 & $0.02^{* *}$ & 0.00 & $0.04^{* *}$ & $0.04^{* *}$ & $0.03^{* *}$ & $0.03^{* *}$ & 0.00 & $0.02^{* *}$ & $0.01^{*}$ & $-0.01^{* *}$ & $0.02^{* *}$ & $0.01^{*}$ & 0.00 & 1.00 & \\
\hline 15 Industry FDI & 0.11 & 0.04 & $0.11^{* *}$ & $-0.01^{*}$ & $0.11^{* *}$ & 0.00 & $0.07^{* *}$ & $-0.06^{* *}$ & 0.00 & 0.00 & $0.12^{* *}$ & $0.17^{* *}$ & $0.03^{* *}$ & $0.01^{\dagger}$ & -0.00 & $0.09^{* *}$ & 1.00 \\
\hline
\end{tabular}

Notes: $\uparrow \mathrm{p}<0.1, * \mathrm{p}<0.05$, and ${ }^{* *} \mathrm{p}<0.01$. 
Table 3 Regression results

\begin{tabular}{|c|c|c|c|c|c|c|}
\hline & \multicolumn{3}{|c|}{ Innovation performance } & \multicolumn{3}{|c|}{ Profitability } \\
\hline & Model 1 & Model 2 & Model 3 & Model 4 & Model 5 & Model 6 \\
\hline \multicolumn{7}{|l|}{ Independent variables } \\
\hline Gov. affiliation (H1) & & $\begin{array}{l}0.05^{* *} \\
(0.00)\end{array}$ & $\begin{array}{l}0.05^{* *} \\
(0.00)\end{array}$ & & & \\
\hline Gov. affiliation (reversed order, $\mathrm{H} 2$ ) & & & & & $\begin{array}{l}0.02 * * \\
(0.00)\end{array}$ & $\begin{array}{l}0.02 * * \\
(0.00)\end{array}$ \\
\hline IPR inefficiency & & $\begin{array}{l}-0.19^{* *} \\
(0.06)\end{array}$ & $\begin{array}{l}-0.40^{* *} \\
(0.08)\end{array}$ & & $\begin{array}{l}0.08 \text { ** } \\
(0.01)\end{array}$ & $\begin{array}{l}0.10 * * \\
(0.03)\end{array}$ \\
\hline \multicolumn{7}{|l|}{ Interactions } \\
\hline Gov. affiliation $\times$ IPR inefficiency $(\mathrm{H} 3)$ & & & $\begin{array}{l}0.15^{* *} \\
(0.04)\end{array}$ & & & \\
\hline Gov. affiliation (reversed order) $\times$ IPR inefficiency $(\mathrm{H} 4)$ & & & & & & $\begin{array}{l}0.02 \\
(0.02)\end{array}$ \\
\hline \multicolumn{7}{|l|}{ Control variables } \\
\hline Firm size & $\begin{array}{l}0.19 * * \\
(0.01)\end{array}$ & $\begin{array}{l}0.18^{* *} \\
(0.01)\end{array}$ & $\begin{array}{l}0.18^{* *} \\
(0.01)\end{array}$ & $\begin{array}{l}-0.02^{* *} \\
(0.00)\end{array}$ & $\begin{array}{l}-0.01 * * \\
(0.00)\end{array}$ & $\begin{array}{l}-0.01 * * \\
(0.00)\end{array}$ \\
\hline Firm age & $\begin{array}{l}0.00^{* * *} \\
(0.00)\end{array}$ & $\begin{array}{l}0.00 * * \\
(0.00)\end{array}$ & $\begin{array}{l}0.00^{* *} \\
(0.00)\end{array}$ & $\begin{array}{l}-0.00^{* *} \\
(0.00)\end{array}$ & $\begin{array}{l}-0.00 \\
(0.00)\end{array}$ & $\begin{array}{l}-0.00 \\
(0.00)\end{array}$ \\
\hline Group affiliation & $\begin{array}{l}0.02 \\
(0.02)\end{array}$ & $\begin{array}{l}0.01 \\
(0.02)\end{array}$ & $\begin{array}{l}0.01 \\
(0.02)\end{array}$ & $\begin{array}{l}-0.02 * * \\
(0.00)\end{array}$ & $\begin{array}{l}-0.01^{* *} \\
(0.00)\end{array}$ & $\begin{array}{l}-0.01 * * \\
(0.00)\end{array}$ \\
\hline Government ownership & $\begin{array}{l}-0.01 \\
(0.01)\end{array}$ & $\begin{array}{l}0.08^{* * *} \\
(0.02)\end{array}$ & $\begin{array}{l}0.09 * * \\
(0.02)\end{array}$ & $\begin{array}{l}-0.04 * * \\
(0.01)\end{array}$ & $\begin{array}{l}-0.07 * * \\
(0.01)\end{array}$ & $\begin{array}{l}-0.07 * * \\
(0.01)\end{array}$ \\
\hline Foreign ownership & $\begin{array}{l}-0.06^{*} \\
(0.03)\end{array}$ & $\begin{array}{l}-0.05^{*} \\
(0.03)\end{array}$ & $\begin{array}{l}-0.05^{*} \\
(0.03)\end{array}$ & $\begin{array}{l}0.03^{*} \\
(0.01)\end{array}$ & $\begin{array}{l}0.03^{*} \\
(0.01)\end{array}$ & $\begin{array}{l}0.03^{*} \\
(0.01)\end{array}$ \\
\hline Export intensity & $\begin{array}{l}0.03 \\
(0.02)\end{array}$ & $\begin{array}{l}0.05^{*} \\
(0.02)\end{array}$ & $\begin{array}{l}0.05^{*} \\
(0.02)\end{array}$ & $\begin{array}{l}-0.02 * * \\
(0.00)\end{array}$ & $\begin{array}{l}-0.03^{* *} \\
(0.01)\end{array}$ & $\begin{array}{l}-0.03^{* *} \\
(0.01)\end{array}$ \\
\hline R\&D intensity & $\begin{array}{l}0.11^{* *} \\
(0.02)\end{array}$ & $\begin{array}{l}0.10^{* *} \\
(0.02)\end{array}$ & $\begin{array}{l}0.10^{* *} \\
(0.02)\end{array}$ & $\begin{array}{l}-0.01 \\
(0.01)\end{array}$ & $\begin{array}{l}0.00 \\
(0.01)\end{array}$ & $\begin{array}{l}0.00 \\
(0.01)\end{array}$ \\
\hline Tangible resources & $\begin{array}{l}0.00 * * \\
(0.00)\end{array}$ & $\begin{array}{l}0.00^{* * *} \\
(0.00)\end{array}$ & $\begin{array}{l}0.00^{* *} \\
(0.00)\end{array}$ & $\begin{array}{l}-0.00 \\
(0.00)\end{array}$ & $\begin{array}{l}-0.00 \\
(0.00)\end{array}$ & $\begin{array}{l}-0.00 \\
(0.00)\end{array}$ \\
\hline Slack resources & $\begin{array}{l}-0.00 \\
(0.00)\end{array}$ & $\begin{array}{l}-0.00 \\
(0.00)\end{array}$ & $\begin{array}{l}-0.00 \\
(0.00)\end{array}$ & $\begin{array}{l}0.00 \\
(0.00)\end{array}$ & $\begin{array}{l}0.00 \\
(0.00)\end{array}$ & $\begin{array}{l}0.00 \\
(0.00)\end{array}$ \\
\hline Industry competition & $\begin{array}{l}-0.42 \\
(0.38)\end{array}$ & $\begin{array}{l}-0.26 \\
(0.39)\end{array}$ & $\begin{array}{l}-0.29 \\
(0.38)\end{array}$ & $\begin{array}{l}0.05 \\
(0.20)\end{array}$ & $\begin{array}{l}0.01 \\
(0.19)\end{array}$ & $\begin{array}{l}0.01 \\
(0.19)\end{array}$ \\
\hline Industry FDI & $\begin{array}{l}0.10 \\
(0.32) \\
\end{array}$ & $\begin{array}{l}-0.03 \\
(0.32) \\
\end{array}$ & $\begin{array}{l}-0.02 \\
(0.32) \\
\end{array}$ & $\begin{array}{l}-0.10 \\
(0.16) \\
\end{array}$ & $\begin{array}{l}-0.08 \\
(0.16) \\
\end{array}$ & $\begin{array}{l}-0.08 \\
(0.16)\end{array}$ \\
\hline Observations & 28,645 & 28,645 & 28,645 & 28,645 & 28,645 & 28,645 \\
\hline Firms & 18,430 & 18,430 & 18,430 & 18,430 & 18,430 & 18,430 \\
\hline F-statistic & $93.53^{* *}$ & $96.12^{* *}$ & $94.37^{* *}$ & $37.69^{* *}$ & $37.48^{* *}$ & $37.01 * *$ \\
\hline Pseudo R square & 0.15 & 0.16 & 0.17 & 0.01 & 0.02 & 0.03 \\
\hline
\end{tabular}

Notes:
(1) $\dagger \mathrm{p}<0.1,{ }^{*} \mathrm{p}<0.05$, and $* * \mathrm{p}<0.01$.

(2) 6 industry dummies, 30 region dummies, and 2 year dummies are included.

(3) Random effects tobit analyses for Models 1-3; Random effects panel analyses for Models 4-6. 
Table 4 Robustness Analyses

\begin{tabular}{|c|c|c|c|c|}
\hline & \multicolumn{2}{|c|}{ Innovation performance } & \multicolumn{2}{|c|}{ Profitability } \\
\hline & Model 1 & Model 2 & Model 3 & Model 4 \\
\hline \multicolumn{5}{|c|}{ (A) Dependent variable: $\log (1+$ new product sales $)(\log ($ total sales $)$ as a control $)$} \\
\hline Gov. affiliation (H1) & $\begin{array}{l}0.95^{* *} * \\
(0.08)\end{array}$ & $\begin{array}{l}1.03 * * \\
(0.08)\end{array}$ & & \\
\hline Gov. affiliation (reversed order) (H2) & & & $\begin{array}{l}0.02 * * \\
(0.00)\end{array}$ & $\begin{array}{l}0.02^{* *} \\
(0.00)\end{array}$ \\
\hline IPR inefficiency & $\begin{array}{l}-5.92 * * \\
(1.17)\end{array}$ & $\begin{array}{l}-11.24 * * \\
(1.64)\end{array}$ & $\begin{array}{l}0.07 * * \\
(0.01)\end{array}$ & $\begin{array}{l}0.08^{*} \\
(0.03)\end{array}$ \\
\hline Gov. affiliation $\times$ IPR inefficiency $(\mathrm{H} 3)$ & & $\begin{array}{l}3.82 * * \\
(0.82)\end{array}$ & & \\
\hline Gov. affiliation (reversed order) $\times$ IPR inefficiency $(\mathrm{H} 4)$ & & & & $\begin{array}{l}0.01 \\
(0.03) \\
\end{array}$ \\
\hline F-statistic & $169.36^{* *}$ & $166.11^{* *}$ & $44.71 * *$ & $44.22 * *$ \\
\hline Pseudo R square & 0.22 & 0.23 & 0.02 & 0.03 \\
\hline \multicolumn{5}{|l|}{ (B) Government affiliation defined as a dummy variable } \\
\hline Higher gov. affiliation (H1) & $\begin{array}{l}0.13 * * \\
(0.01)\end{array}$ & $\begin{array}{l}0.13 * * \\
(0.02)\end{array}$ & & \\
\hline Lower gov. affiliation (H2) & & & $\begin{array}{l}0.03^{*} \\
(0.02)\end{array}$ & $\begin{array}{l}0.03^{*} \\
(0.02)\end{array}$ \\
\hline IPR inefficiency & $\begin{array}{l}-0.18 * * \\
(0.06)\end{array}$ & $\begin{array}{l}-0.18 * * \\
(0.06)\end{array}$ & $\begin{array}{l}0.08 * * \\
(0.01)\end{array}$ & $\begin{array}{l}0.08^{* *} \\
(0.01)\end{array}$ \\
\hline Higher gov. affiliation $\times$ IPR inefficiency $(\mathrm{H} 3)$ & & $\begin{array}{l}0.03 \dagger \\
(0.02)\end{array}$ & & \\
\hline Lower gov. affiliation $\times$ IPR inefficiency $(\mathrm{H} 4)$ & & & & $\begin{array}{r}0.04 \\
(0.04) \\
\end{array}$ \\
\hline F-statistic & $73.67 * *$ & $72.79^{* *}$ & $7.58 * *$ & $7.43 * *$ \\
\hline Pseudo R square & 0.10 & 0.11 & 0.01 & 0.02 \\
\hline \multicolumn{5}{|c|}{ (C) IPR inefficiency is defined as the number of cases received by the court weighted by provincial population in a reversed order } \\
\hline Gov. affiliation (H1) & $\begin{array}{l}0.05^{* *} * \\
(0.00)\end{array}$ & $\begin{array}{l}0.05^{* *} * \\
(0.00)\end{array}$ & & \\
\hline Gov. affiliation (reversed order) (H2) & & & $\begin{array}{l}0.02 * * \\
(0.00)\end{array}$ & $\begin{array}{l}0.02 * * \\
(0.00)\end{array}$ \\
\hline IPR inefficiency & $\begin{array}{l}-0.06 \dagger \\
(0.03)\end{array}$ & $\begin{array}{l}-0.11 * * \\
(0.04)\end{array}$ & $\begin{array}{l}0.10 \dagger \\
(0.06)\end{array}$ & $\begin{array}{l}0.13 \dagger \\
(0.08)\end{array}$ \\
\hline Gov. affiliation $\times$ IPR inefficiency $(\mathrm{H} 3)$ & & $\begin{array}{l}0.03 * * \\
(0.00)\end{array}$ & & \\
\hline Gov. affiliation (reversed order) $\times$ IPR inefficiency $(\mathrm{H} 4)$ & & & & $\begin{array}{l}-0.02 \\
(0.01) \\
\end{array}$ \\
\hline F-statistic & $77.20 * *$ & $76.27 * *$ & $8.65^{* *}$ & $8.83 * *$ \\
\hline
\end{tabular}




\begin{tabular}{|c|c|c|c|c|}
\hline Pseudo R square & 0.11 & 0.12 & 0.01 & 0.02 \\
\hline \multicolumn{5}{|l|}{ (D) Full sample including non-affiliated firms } \\
\hline Gov. affiliation (H1) & $\begin{array}{l}0.05 * * \\
(0.00)\end{array}$ & $\begin{array}{l}0.05^{* * *} \\
(0.00)\end{array}$ & & \\
\hline Gov. affiliation (reversed order) (H2) & & & $\begin{array}{l}0.01 * * \\
(0.00)\end{array}$ & $\begin{array}{l}0.01 \text { ** } \\
(0.00)\end{array}$ \\
\hline IPR inefficiency & $\begin{array}{l}-0.25^{* *} \\
(0.03)\end{array}$ & $\begin{array}{l}-0.24 * * \\
(0.03)\end{array}$ & $\begin{array}{l}0.06^{* *} \\
(0.01)\end{array}$ & $\begin{array}{l}0.06^{* *} \\
(0.01)\end{array}$ \\
\hline Gov. affiliation $\times$ IPR inefficiency (H3) & & $\begin{array}{l}0.10^{* *} \\
(0.03)\end{array}$ & & \\
\hline Gov. affiliation (reversed order) $\times$ IPR inefficiency $(\mathrm{H} 4)$ & & & & $\begin{array}{c}-0.01 \\
(0.01) \\
\end{array}$ \\
\hline F-statistic & $263.56 * *$ & $258.57 * *$ & $99.17 * *$ & $97.25 * *$ \\
\hline Pseudo R square & 0.10 & 0.11 & 0.03 & 0.04 \\
\hline \multicolumn{5}{|l|}{ (E) Sample with extended period (2005-2009) } \\
\hline Gov. affiliation (H1) & $\begin{array}{l}0.10 * * \\
(0.00)\end{array}$ & $\begin{array}{l}0.10 * * \\
(0.00)\end{array}$ & & \\
\hline Gov. affiliation (reversed order) (H2) & & & $\begin{array}{l}0.02^{* *} \\
(0.00)\end{array}$ & $\begin{array}{l}0.02^{* * *} \\
(0.00)\end{array}$ \\
\hline IPR inefficiency & $\begin{array}{l}-0.31 * * \\
(0.02)\end{array}$ & $\begin{array}{l}-0.35^{* *} \\
(0.02)\end{array}$ & $\begin{array}{l}0.03 \\
(0.02)\end{array}$ & $\begin{array}{l}0.05 \\
(0.04)\end{array}$ \\
\hline Gov. affiliation $\times$ IPR inefficiency $(\mathrm{H} 3)$ & & $\begin{array}{l}0.03 * * \\
(0.01)\end{array}$ & & \\
\hline Gov. affiliation (reversed order) $\times$ IPR inefficiency $(\mathrm{H} 4)$ & & & & $\begin{array}{l}0.02 \\
(0.02) \\
\end{array}$ \\
\hline F-statistic & $65.86^{* *}$ & $64.36^{* *}$ & $43.23^{* *}$ & $42.49 * *$ \\
\hline Pseudo R square & 0.19 & 0.20 & 0.01 & 0.02 \\
\hline
\end{tabular}

(1) 18,430 firms and 28,645 observations for sections (A), (B), (C), and (D); 60,612 firms and 116,666 observations for section (E); 18,430 firms and 36,756 observations for section (F).

(2) $\dagger \mathrm{p}<0.1,{ }^{*} \mathrm{p}<0.05$, and ** $\mathrm{p}<0.01$.

(3) Results for control variables are not shown to save space.

(4) Random effects tobit analyses for Models 1-2; Random effects panel analyses for Models 3-4 